\title{
IMPROVEMENTS IN COMPUTATIONAL MODELLING OF
}

\section{SLIDE BEARINGS}

\section{ONDŘEJ MARŠÁLEK, PAVEL NOVOTNÝ, LUBOMÍR DRÁPAL, VÁCLAV PİŠTĚK}

Institute of Automotive Engineering, Brno University of Technology, Technická 2896/2, 61669 Brno, Czech Republic Tel.: +420 541142 272, Fax: +420 541143 354, E-mail: marsalek@iae.fme.vutbr.cz

\section{SHRNUTÍ}

Záměrem tohoto článku je představit inovace v oblasti výpočtového modelování kluzných ložisek pohonných jednotek. Tyto inovace spočívají, mimo jiné, v rozšǐření modelu o podmínky smišeného mazání. Vstupní data pro detailní výpočty jednotlivých kluzných ložisek jsou poskytována výpočtovým modelem pohonné jednotky vyšší úrovně, tzv. virtuálním motorem. Výsledky těchto výpočtů slouží jako téměř nezbytné informace pro správný návrh parametrů různých typů kluzných ložisek. Prezentované metody jsou založeny na nových programových nástrojích, vyvinutých autory během výzkumu, a také na komerčně dostupných aplikacích typu ANSYS nebo ADAMS. Výpočtové modely pohonných jednotek vyšší úrovně zahrnuji pružná tělesa na základě redukovaných MKP modelů. Nově vyvinuté vysoce specializované programové nástroje jsou sestaveny v programovacích jazycích Fortran a Matlab.

\section{KLIIČOVÁ SLOVA: KLUZNÉ LOŽISKO, MAZÁNÍ, KLOPENÍ ČEPU, VLASTNOSTI OLEJE, MAZACÍ MEZERA}

\section{ABSTRACT}

The intent of this paper is to present new improvements in the modelling of a powertrain slide bearing incorporating mixed lubrication conditions. The Virtual Engine as a model of the powertrain provides input data for detailed calculations of individual slide bearings. The results of these calculations serve as essential information for the correct parameter design of various types of slide bearings. The presented methods are based on new software tools developed by the authors during the research and also on commercial tools such as ANSYS or ADAMS. The computational models of the target powertrains incorporate flexible bodies (based on conversed FE models). The newly developed and highly specialized software tools are written in Fortran and Matlab.

KEYWORDS: SLIDE BEARING, LUBRICATION, PIN TILTING, OIL PROPERTIES, OIL FILM GAP

\section{INTRODUCTION}

A slide bearing is an important part of many types of machinery including most powertrains. Interactions between a crankshaft and a crankcase or a camshaft and a crankcase (for OHV valvetrain type) can be presented as examples.

The progress of computation modelling brings higher demands on the level of slide bearing computational models. Present computational models enable the description of a slide bearing behaviour in great detail. These models are often very complicated and require long solution times, even when only one slide bearing model is being solved. The target engine includes tens of slide bearings; therefore, the level of slide bearing modelling has to be carefully considered.

\section{BACKGROUND RESEARCH}

The mechanism of hydrodynamic lubrications was formulated independently by three men way back in history. These were
Russian, N. P. Petrov (1836-1920) and two Britons, B. Tower (1845-1904) and O. Reynolds (1842-1912).

In the course of time, the hydrodynamic theory has been further developed by a relatively large number of authors. The enclosed list of references [1, 2, 3, 4, and 5] shows a few examples. Subsequently, the hydrodynamic theory was extended to cover many mechanical components, for instance, gears, piston rings and cylinder interaction.

Applications of slide bearing models for dynamics simulations of powertrain parts therefore require the consideration of different model features. Advanced computational models of slide bearings can include, among others, these influences:

- Pin tilting,

- Elastic deformations of bearing shells or pins (EHD),

- Oil cavitation,

- Boundary lubrication,

- Oil density changes, 
- Pressure dependent oil properties,

- Temperature dependent oil properties,

- Shear stresses in oil.

\subsection{PIN TILTING}

A standard solution of the Reynolds equation $[6,7]$ does not consider tilting of a pin in a bearing shell. Symmetrical pressure distribution is then a result of this solution. The loading capacity of a slide bearing model is considered only in a radial direction, which means that only a radial force is considered. This solution approach is often successful, but sometimes it has to be extended, mainly for modern bearings with high bearing diameter/width ratios. The main bearings of a cranktrain carry high moments; therefore, pin tilting should be incorporated.

\subsection{ELASTIC DEFORMATIONS OF SHELLS OR PINS}

$\mathrm{HD}$ theory presumes that a bearing shell and a pin are without any deformations. Therefore, a relative eccentricity can reach a maximum value of 1 . Slide bearings of modern combustion engines are highly loaded and the relative eccentricity sometimes exceeds the value of 1 . This is caused by elastic deformations, mainly of the bearing shell, but commonly also due to the pin deformation. These conditions can be found in some modern turbocharged diesel engines.

At the present time there are many EHD models, for example, Thomas [1], Goenka [8], Knoll [9] and others. EHD calculation results indicate the significant influence of elastic deformations on computed pressure peaks in slide bearings. The peak pressures computed by EHD solution are less than peak pressures computed by HD solution, but they are distributed on large surfaces. The minimal film thicknesses can be slightly different, mainly for peak pressures.

\subsection{OIL CAVITATION}

Cavitation usually occurs in the regions of diverging lubricated contact gaps and is caused by sub-ambient pressures in the lubricant. These low pressures lead to a transformation of liquid into gas-liquid mixture. Different types of cavitation models have been proposed over the years to replicate this behaviour in theoretical simulations. Some of the algorithms preserve lubricant mass continuity whereas others do not, Sahlin [4]. The cavitation must always be incorporated into the computational model.

\subsection{BOUNDARY LUBRICATION}

When local bearing clearance values drop to extremely small levels, surface asperities on a pin and a bearing shell start interacting with each other and create boundary lubrication conditions, Gulvadi [10]. A boundary lubrication solution was published, for example, by Greenwood [11].

\subsection{PRESSURE DEPENDENT OIL. PROPERTIES}

Generally, oil properties and oil viscosity are dependent on pressure. High viscosity differences can be achieved especially when machinery parts include point or line contacts (roller bearings or a cam/tappet contact).

Barus's exponential formula is one of the simplest descriptions of oil viscosity vs. pressure. A more complicated but physically more accurate formula was introduced by Roelands [12]. This can also be used for EHD study.

Peak pressure values of slide bearings reach hundreds of $\mathrm{MPa}$, but these pressures are located only on small areas of oil film. Pressure dependent oil viscosity dramatically increases the complexity of the slide bearing model. It cannot be used correctly without an EHD solution in particular. Therefore, pressure dependency of oil viscosity is neglected and oil viscosity is treated as constant across the whole oil film. Thereby, some inaccuracy can exist, but only in areas with high peaks of oil pressure.

The relationship between oil density and pressure can also be neglected, because actual oil density $\rho$ is only 1.34 times higher $\left(\rho=1.34 \rho_{0}\right)$ for pressures approaching infinity $(p \rightarrow \infty)$. The maximum density differences for peak pressures in slide bearings are about $5 \%$.

\subsection{TEMPERATURE DEPENDENT OIL PROPERTIES}

The influence of oil temperature on its viscosity is significant. Therefore, it is necessary to incorporate the temperature behaviour in this form into a computational model. Generally, the oil temperature of the whole gap oil film is not constant. However, variable oil temperatures considerably increase a model's complexity.

Therefore, oil temperature is treated as a constant for the computational model. This assumption enables the inclusion of temperature influences after the hydrodynamic solution according to temperatures determined from similar engines.

\section{FAST HYDRODYNAMIC MODEL FOR MULTI-BODY DYNAMICS}

\subsection{THEORETICAL ASSUMPTIONS}

Solutions of tens of EHD slide bearing models in a powertrain model simultaneously seem to be extremely difficult and do not provide any fundamental benefits for general dynamics. The multi-body models therefore incorporate a compromise 
approach using the HD solution with elastic bearing shells and can be termed the (E)HD approach.

A HD approach assumes that the pin and bearing shell shapes are ideal cylindrical parts. The pin and the bearing shell are rigid bodies without any deformations. An oil gap between the pin and the shell is filled up with the oil and the gap proportions are small in comparison with pin or bearing shell proportions. Only hydrodynamic frictions occur, lubricating oil is incompressible and oil flow is laminar.

Generally, oil temperature has a significant influence on slide bearing behaviour. Oil temperature is treated as a constant for whole oil film of the bearing. This assumption enables inclusion of temperature influences after the hydrodynamic solution according to temperatures determined from similar engines.

In general, if the equation of the motion and the continuity equation are transformed for cylindrical forms of bearing oil gap together with restrictive conditions [2], the behaviour of oil pressure can be described by Reynolds differential equation. This frequently used equation is a derivative for a bearing oil gap [6] or [7] and can be written in the form:

$$
\frac{\partial}{\partial x}\left(h^{3} \frac{\partial p}{\partial x}\right)+\frac{\partial}{\partial z}\left(h^{3} \frac{\partial p}{\partial z}\right)=6 \eta\left(U \frac{\partial h}{\partial x}+2 \frac{\partial h}{\partial t}\right)
$$

where $p$ is pressure, $h$ is oil film gap, $\eta$ is dynamic viscosity of oil and $U$ is effective velocity. The oil film gap is defined as:

$$
h=R-r+e \cos (\varphi) \text {, }
$$

where $R$ is the shell radius, $r$ the pin radius, $e$ the pin eccentricity and $\varphi$ is an angle about the pin axis.

The following relationships can be defined as:

$$
\begin{aligned}
& \varphi=\frac{x}{R}=\frac{2 x}{D} \quad, \quad Z=\frac{2 Z}{B}, \\
& \psi=\frac{s}{D}=\frac{R-r}{R} \approx \frac{R-r}{r} \quad, \quad \varepsilon=\frac{e}{R-r},
\end{aligned}
$$

where $D$ is the shell diameter, $B$ is the width of the bearing, $Z$ is a dimensionless co-ordinate in the bearing axis direction, $s$ is bearing clearance, $\psi$ is an independent bearing clearance and $\varepsilon$ is dimensionless relative eccentricity.

A definition of a dimensionless oil film gap $H$ in relation to angle can be used:

$$
H^{*}(\varphi) \approx 1+\varepsilon \cos \varphi
$$

Additionally, the pressures in the oil film can be replaced by dimensionless pressures as:

$$
\Pi_{\mathrm{D}}=\frac{p_{\mathrm{D}} \psi^{2}}{\eta \bar{\omega}} \quad \text { and } \quad \Pi_{V}=\frac{p_{V} \psi^{2}}{\eta \dot{\varepsilon}}
$$

where $\Pi_{D}$ denotes dimensionless pressure for a tangential movement of the pin, $\Pi_{v}$ is dimensionless

pressure for a radial movement of the pin, $\bar{\omega}$ is effective angular velocity and $\varepsilon^{\&}$ is a derivative of dimensionless eccentricity with respect of time.

Pin tilting angles can be introduced as:

$$
\gamma=\frac{\operatorname{tg} \gamma^{*}}{\operatorname{tg} \gamma_{\max }^{*}} \quad \text { and } \quad \delta=\frac{\operatorname{tg} \delta^{*}}{\operatorname{tg} \delta_{\text {max }}^{*}}
$$

where $\gamma$ is dimensionless pin tilting angle in the narrowest oil film gap and $\delta$ is a dimensionless relative tilting angle in the plane perpendicular to the plane of narrowest oil film gap. Symbol $\gamma^{*}$ denotes the real tilting angle in the plane of the narrowest oil film gap and $\gamma_{\text {max }}^{*}$ denotes a maximum possible tilting angle in the plane of the narrowest oil film gap for the given eccentricity. Symbol $\delta^{*}$ is the real tilting angle in the plane perpendicular to the plane of narrowest oil film gap and $\delta_{\text {max }}^{*}$ is a maximum real tilting angle in the plane perpendicular to the plane of narrowest oil film gap for the given eccentricity.

The definition of pin tilting angles is defined by Figure 1 .

The definition of general and maximum tilting angle in a plane of the narrowest oil film gap is presented by Figure 2 .

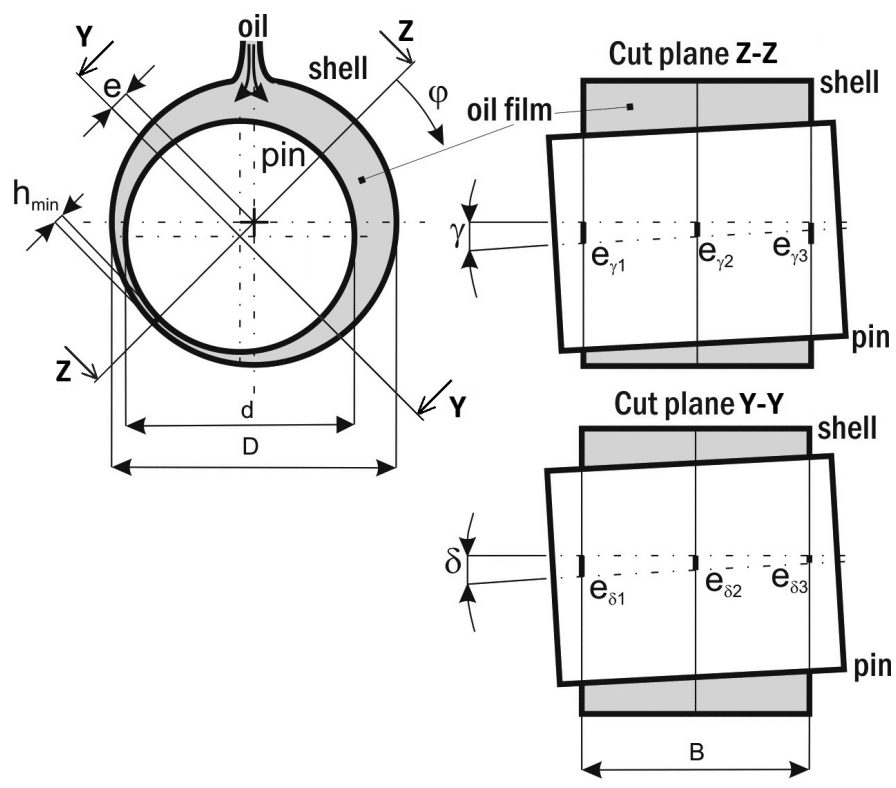

FIGURE 1: Definition of tilting angles of pin OBRÁZEK 1: Určení klopných úhlů čepu 
General tilted position Maximal tilted position

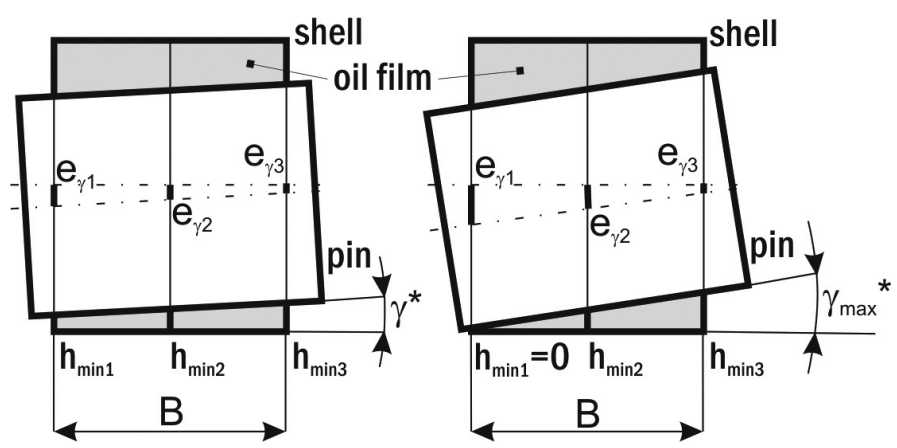

FIGURE 2: Description of real tilting angles in plane of the narrowest oil film gap OBRÁzEK 2: Popis skutečných klopných úhlů v rovině nejužší mazací mezery

The final definition of the dimensionless oil film gap depending on tilting angles is:

$$
\begin{aligned}
H & =H(\varphi, \varepsilon, \gamma, \delta)= \\
& =1+\varepsilon \cos \varphi-\gamma Z \cos \varphi+\varepsilon \gamma Z \cos \varphi-\delta Z \sin \varphi)
\end{aligned}
$$

which includes a dependency on two tilting angles.

If the dimensionless oil film gap is used for the Reynolds equations for tangential and radial movements of the pin, then the Eq. (1) can be rewritten into two separate equations, but with a modified definition of the dimensionless oil film gap.

$$
\begin{aligned}
& \frac{\partial}{\partial \varphi}\left(H^{3} \frac{\partial \Pi_{D}}{\partial \varphi}\right)+\frac{D^{2}}{B^{2}} \frac{\partial}{\partial Z}\left(H^{3} \frac{\partial \Pi_{D}}{\partial Z}\right)=6 \frac{\partial H}{\partial \varphi}, \\
& \frac{\partial}{\partial \varphi}\left(H^{3} \frac{\partial \Pi_{V}}{\partial \varphi}\right)+\frac{D^{2}}{B^{2}} \frac{\partial}{\partial Z}\left(H^{3} \frac{\partial \Pi_{V}}{\partial Z}\right)=12 \cos \varphi .
\end{aligned}
$$

Likewise, the dimensionless pressure is modified as follows:

$$
\bar{\Pi}=\Pi H^{\frac{3}{2}} .
$$

If Eqs. (3) to (6) are substituted into Eqs. (8) and (9), the final forms of Reynolds equations are:

$$
\begin{aligned}
& \frac{\partial^{2} \bar{\Pi}_{D}}{\partial \varphi^{2}}+\left(\frac{D}{B}\right)^{2} \frac{\partial^{2} \bar{\Pi}_{D}}{\partial Z^{2}}+a(\varphi, \varepsilon, Z, \gamma, \delta) \bar{\Pi}_{D}= \\
& =b_{D}(\varphi, \varepsilon, Z, \gamma, \delta)
\end{aligned}
$$

$$
\begin{aligned}
& \frac{\partial^{2} \bar{\Pi}_{V}}{\partial \varphi^{2}}+\left(\frac{D}{B}\right)^{2} \frac{\partial^{2} \bar{\Pi}_{V}}{\partial Z^{2}}+a(\varphi, \varepsilon, Z, \gamma, \delta) \bar{\Pi}_{V}= \\
& =b_{V}(\varphi, \varepsilon, Z, \gamma, \delta)
\end{aligned}
$$

The equation term $a(\varphi, \varepsilon, Z, \gamma, \delta)$ is defined as:

$$
\begin{aligned}
& a(\varphi, \varepsilon, Z, \gamma, \delta)= \\
& =-\frac{3}{4} H^{-2}\left[2 H H_{\varphi \varphi}+H_{\varphi}^{2}+\left(\frac{D}{B}\right)^{2} H_{z}^{2}\right]
\end{aligned}
$$

and the equation terms $b_{D}(\varphi, \varepsilon, Z, \gamma, \delta)$ and $b_{V}(\varphi, \varepsilon, Z, \gamma, \delta)$ are defined as:

$$
\begin{aligned}
& b_{V}(\varphi, \varepsilon, Z, \gamma, \delta)=6 H^{-\frac{3}{2}} H_{\varphi}, \\
& b_{D}(\varphi, \varepsilon, Z, \gamma, \delta)=12 H^{-\frac{3}{2}} \cos \varphi
\end{aligned}
$$

Functions $H_{\varphi^{\prime}} H_{Z}$ and $H_{\varphi \varphi}$ are partial derivatives of the oil film gap and can be found in [13]. Eqs. (11) and (12) are solved numerically.

\subsection{NUMERICAL ALGORITHMS FOR FAST HD BEARING SOLUTIONS}

The FDM (Finite Difference Method) is used for numeric solutions of the Reynolds equation. The FDM in basic form uses a constant integration step; however, this strategy can be disadvantageous because in the case of very high pin eccentricities, the oil film pressure becomes concentrated in small areas and it is necessary to use a very small integration step. This leads to higher computational models. Therefore, the modified FDM using variable integration steps and multi-grid strategy has been developed.

The iterative solution starts by using a very coarse computational grid. After a few iterations, the results are approximated to the denser grid and again a few iterations are performed. The new results are used for a re-meshing algorithm to generate a new variable computational grid. The grid density is changed in relation to prescribed conditions (a pressure gradient). Three point integration schemes are chosen for the solution because for small integration steps it is very fast and the accuracy is similar to a five-point integration scheme. Figure 3 presents an example of computational grid for FDM with a variable integration step. 


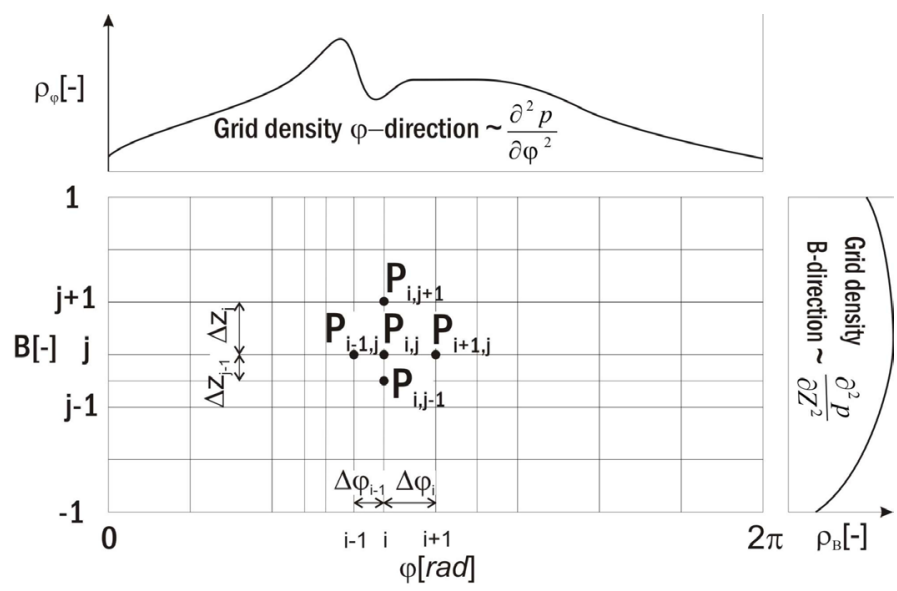

FIGURE 3: Computational grid for FDM with variable integration step OBRÁZEK 3: Výpočetní sít pro MKD s proměnným integračním krokem

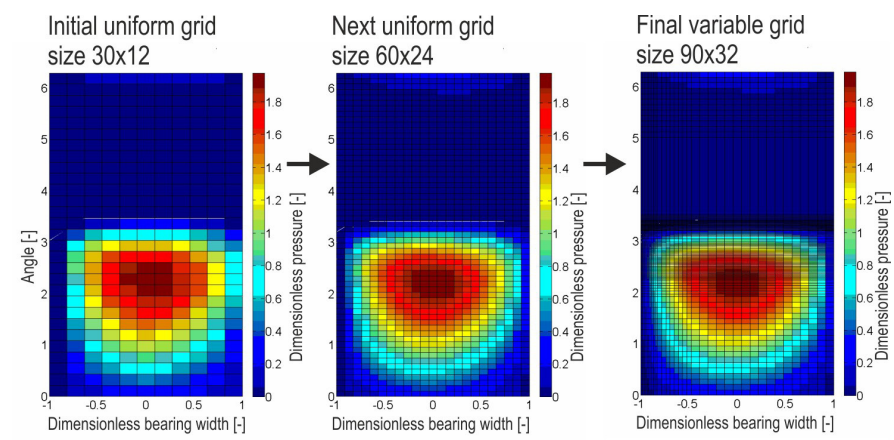

FIGURE 4: Solution results of Reynolds equation for tangential pin movement: relative eccentr. $\varepsilon=0.8$, first pin tilting angle $\gamma=0.8$ and second tilt. angle $\delta=0$

OBRÁZEK 4: Výsledky řešení Reynoldsovy rovnice pro tangenciální pohyb čepu: relativní excentricita $\varepsilon=0.8$, první klopný úhel $\gamma=0.8$ a druhý klopný úhel $\delta=0$
The resulting formula for iterative solution of dimensionless pressure at point $i, j$ defines Eq. (20).The formula for the numerical solution of Eq. (20) is different for tangential and radial pin movement only in the term $b_{D}$ (for tangential pin movement) and $b_{V}$ (for radial pin movement).

The solution approach with variable integration steps presumes sufficient density of a solution grid according to pressure differentiations with respect to the bearing angle and bearing width. This strategy enables the solving of problematic pressure zones in an acceptable solution time.

Eq. (20) is solved iteratively for the tangential pin movement as well as for the radial pin movement. Initial and boundary conditions are the same for both solutions. The first boundary condition describes:

$$
p_{\left(z= \pm \frac{B}{2}\right)}=0 \rightarrow \Pi_{(Z= \pm 1)}=0
$$

The only initial condition describes:

$$
p_{(\varphi=0)}=0 \rightarrow \Pi_{(\varphi=0)}=0 \text { for the first iteration. }
$$

This initial condition is used only for the first iteration and after that it is replaced by the cyclic boundary condition:

$$
p_{(\varphi=0)}=p_{(\varphi=2 \pi)} \rightarrow \Pi_{(\varphi=0)}=\Pi_{(\varphi=2 \pi)} .
$$

The cavitation condition is included during the numerical solution. This condition resets negative pressures to zero values:

$$
p=0 \in p<0 \rightarrow \Pi=0 \in \Pi<0
$$

Eq. (19) describes as much as possible the conditions that occur in the real physical process and does not allow negative pressures in liquids (cavitation).

$$
\bar{\Pi}_{i, j_{D, V}}=\frac{\frac{\frac{1}{\Delta \varphi_{i}} \bar{\Pi}_{i+1, j}+\frac{1}{\Delta \varphi_{i-1}} \bar{\Pi}_{i-1, j}}{\Delta \varphi_{j}+\Delta \varphi_{j-1}}+2 \frac{D^{2}}{B^{2}} \frac{\frac{1}{D Z_{j}} \bar{\Pi}_{i, j+1}+\frac{1}{\Delta Z_{j-1}} \bar{\Pi}_{i, j-1}}{\Delta Z_{j}+\Delta Z_{j-1}}-b_{D, V}}{\frac{2}{\Delta \varphi_{j} \Delta \varphi_{j-1}}+\frac{D^{2}}{B^{2}} \frac{2}{\Delta Z_{j} \Delta Z_{j-1}}-a} .
$$

Figure 4 presents solution results of a modified Reynolds equation for tangential pin movement, relative eccentricity $\varepsilon=$ 0.8 , first pin tilting angle $\gamma=0.8$ and second tilting angle $\delta=0$. The computed pressure distributions have to be transferred to equivalent force systems for a solution in MBS. Pressure on an elementary surface can be imagined as an elementary force $d F$ on this elementary surface $d S$. Integral values are dimensionless reaction forces $F$ and reaction moments $M$ and can be found by an integration of pressure across the whole bearing surface with coordinates $\varphi$ and $z$.

The equivalent force system including resulting force and moment can also be replaced by a force acting on an $\operatorname{arm} \xi$. 


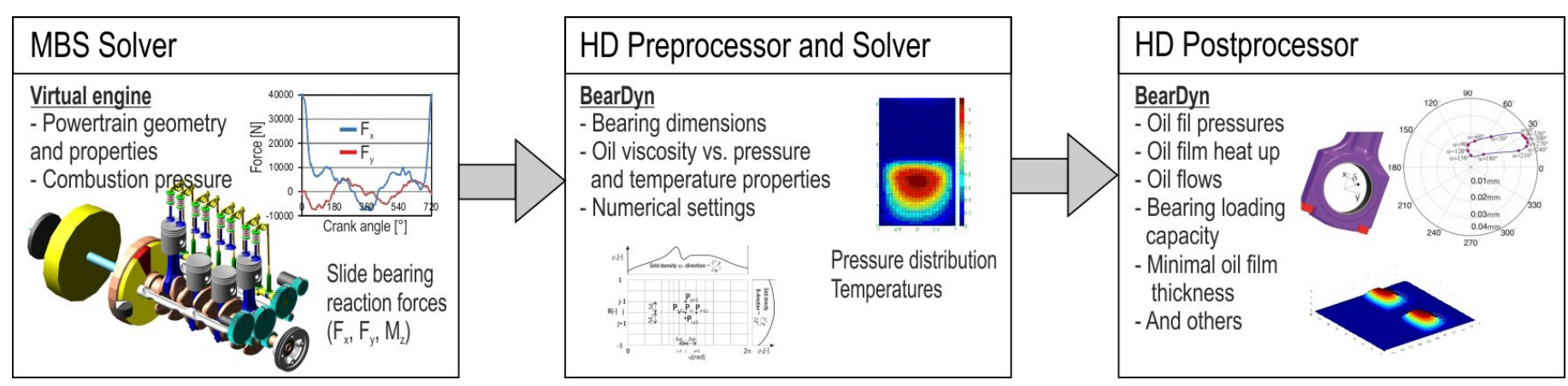

FIGURE 5: HD calculation principles

OBRÁZEK 5: Principy HD výpočtu

Hydrodynamic databases include integral values $\Phi_{1 D^{\prime}} \Phi_{2 D^{\prime}} \Phi_{1 D^{p}}$ $\Theta_{1 D^{\prime}} \Theta_{2 D^{\prime}} \Theta_{1 V}$ for chosen ratios $D / B$ and pin tilting. Resulting forces and moments $\left(F_{1 D}, F_{2 D}, F_{1 V}, M_{1 D^{\prime}} M_{2 D^{\prime}} M_{1 V}\right)$ inserted into MBS can be obtained by an inclusion of bearing sizes, bearing clearances, dynamic viscosity and pin kinematic values.

\section{HD MODEL}

\section{FOR DETAILED BEARING DESIGN}

\subsection{THEORETICAL BACKGROUND}

Friction loss solutions of low loaded powertrain slide bearings incorporating main and crank pin bearings, camshaft bearings or balancing shaft bearings can neglect the elastic deformations. The solution is based on the Reynolds equation in a more general form than Eq. (1)

$$
\frac{\partial}{\partial x}\left(\frac{\rho h^{3}}{12 \eta} \frac{\partial p}{\partial x}\right)+\frac{\partial}{\partial y}\left(\frac{\rho h^{3}}{12 \eta} \frac{\partial p}{\partial y}\right)-U \frac{\partial(\rho h)}{\partial x}-\frac{\partial(\rho h)}{\partial t}=0
$$

Oil viscosity in relation to pressure can be expressed with the use of Roelands's relationship [12].

The solution of a hydrodynamic problem requires reaction forces $(F x$ a $F y)$ and angular velocity $\omega$. These values are obtained from some type of engine computational model such as Virtual Engine. Figure 5 shows the principles of the transfer of reaction forces and angular velocities from the MBS program to the specialized programs written by the author.

Subsequently, the force equilibrium condition is solved

$$
\left(\begin{array}{l}
f x \\
f y
\end{array}\right)=f=F_{\text {OUT }}+F_{I N}(\varepsilon, \delta, \omega)
$$

where $F_{\text {OUT }}$ is a matrix including outer forces $\left(F_{X}\right.$ and $\left.F_{Y}\right)$ obtained from the virtual engine, $F_{I N}$ is a matrix including forces calculated from oil film pressures, $\varepsilon$ is relative eccentricity and $\delta$ is an angle of a minimal oil film gap compared with a coordinate system.
Oil film forces in axes $X$ and $Y$ can be calculated as

$$
\begin{aligned}
& F_{\text {OUT }_{-} X}= \\
& =-\iint_{S} p \cos (\phi-\delta) \mathrm{d} S=-\int_{-\frac{B}{2}}^{\frac{B}{2}} \int_{0}^{2 \pi} p_{D} \cos (\phi-\delta) R \mathrm{~d} \phi \mathrm{d} y, \\
& F_{\text {OUT }_{-} Y}= \\
& =-\iint_{S} p \sin (\phi-\delta) \mathrm{d} S=-\int_{-\frac{B}{2}}^{\frac{B}{2}} \int_{0}^{2 \pi} p_{D} \sin (\phi-\delta) R \mathrm{~d} \phi \mathrm{d} y .
\end{aligned}
$$

\subsection{NUMERICAL SOLUTION FOR DETAILED HD}

\section{BEARING MODEL}

The aim of the force equilibrium condition is to find input parameters ( $\varepsilon$ and $\delta$ ) minimizing the $f$ function. In the case of a numeric solution, the $f$ function has to be smaller than the chosen error. An iterative algorithm incorporates Newton's method and can be suggested as:

$$
\left(\begin{array}{c}
\varepsilon_{k+1} \\
\delta_{k+1}
\end{array}\right)=q_{k+1}=q_{k}+\Delta q_{k}
$$

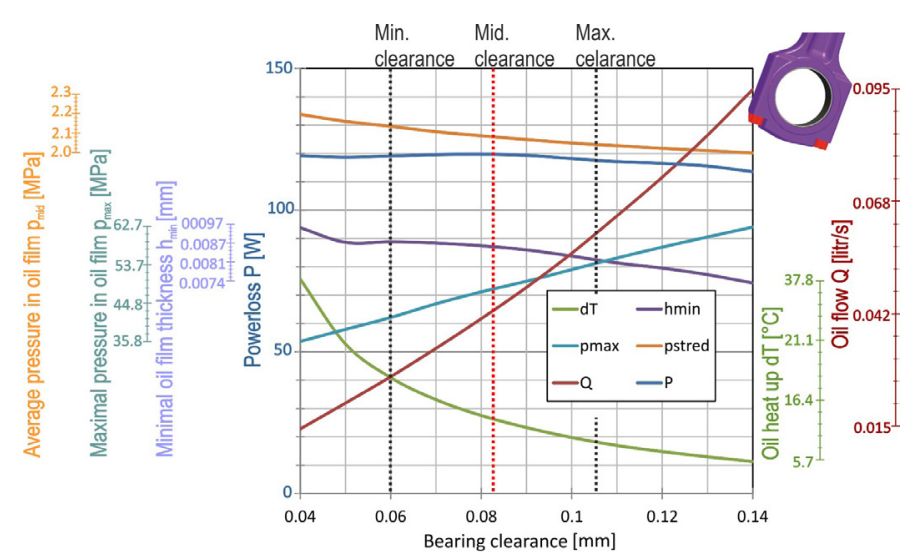

FIGURE 6: Calculation results for pin bearing of diesel engine OBRÁzEK 6: Výsledky výpočtů ojničního ložiska vznětového spalovacího motoru 


$$
\Delta q_{k}=J\left(q_{k}\right)^{-1} f\left(q_{k}\right)
$$

where $q_{k}$ is a matrix of generalised coordinates in step $k_{\imath} J$ is Jacobian or tangent matrix and can be calculated as:

$$
J\left(q_{k}\right)=\left[\begin{array}{ll}
\frac{\partial f x}{\partial \varepsilon} & \frac{\partial f x}{\partial \delta} \\
\frac{\partial f y}{\partial \varepsilon} & \frac{\partial f y}{\partial \delta}
\end{array}\right]
$$

Jacobian (8) is solved numerically, when for every step $k$, the function $f$ is evaluated in axes $X$ and $Y$ :

$f x\left(\varepsilon_{k}\right), f y\left(\delta_{k}\right), f x\left(\varepsilon_{k}+\Delta \varepsilon_{k}\right)$ and $f y\left(\delta_{k}+\Delta \delta_{k}\right)$.

If the pressure distribution in the oil is known, the friction moment can be calculated as:

$$
M_{t}=R \iint_{S}\left(\frac{\eta \omega R}{h}-\frac{h}{2} \frac{\partial p}{\partial x}\right) \mathrm{d} S
$$

\subsection{RESULT EXAMPLES}

The proposed solution approach can in principle be used for any possible slide bearing, but there can be inaccuracies for high loaded bearings of some modern engines. This is caused mainly by high elastic deformations of bearing shells.

Figure 6 presents calculation results for a pin bearing of a typical diesel engine used in a heavy duty car category. The bearing clearance is an independent parameter and it influences output results such as pressures in oil film and oil heating. The results provide basic data for bearing designers in the powertrain development process.

\section{CONCLUSION}

In the stage of powertrain development, a large number of computational approaches have been utilized to reduce costs and accelerate the development. The computational methods presented in this paper represent modern computational methods which can be used in the initial phase of a powertrain development and also in the phase of parameter tuning of existing bearing designs. These methods often require at least some initial design of the main engine parts, mainly those which are highly loaded. These methods enable the design of engine parts in great detail satisfying the target criteria without long and expensive measurements.

\section{ACKNOWLEDGEMENTS}

This research has been realized using the support of Technology Agency of the Czech Republic, programme Centres of Competence, project no. TE01020020 Josef Božek Competence Centre for Automotive Industry and with the help of the project FSI-S-11-8 granted by specific university research of Brno University of Technology. This support is gratefully acknowledged.

\section{REFERENCES}

[1] Thomas S. (2007). Analyse des Betriebsverhaltens von Kurbelwellengleitlagern mittels TEHD-Berechnungen. Ph.D. Thesis. Aachen: RWTH Aachen, Germany.

[2] Wang X., Zhu K. (2006). Numerical analysis of journal bearings lubricated with micropolar fluids including thermal and cavitation effects. In Tribology International 39. pp. 227-237. Elsevier.

[3] Oujja R. (2006). A new method for cavitations approximation in some general lubrication devices. In Applied Mathematics and Computation 181. Elsevier.

[4] Sahlin F., Almqvist A. (2007). A cavitation algorithm for arbitrary lubricant compressibility. In Tribology International 40. Elsevier.

[5] Knoll G., Lechtape-Grüter R. (2006). Simulationstools für strukturdynamisch/ elastohydrodynamisch gekoppelte Motorkomponenten. Universität Gh Kastel, Germany.

[6] Butenschön H., J. (1976). Das hydrodynamische, zylindrische Gleitlager endlicher Breite unter instationärer Belastung. Ph.D. Thesis. Karlsruhe: Universität Karlsruhe.

[7] Rebbert M. (2000). Simulation der Kurbewellendynamik unter Berücksichtigung der hydrodynamischen Lagerung zur Lösung motorakusticher Fragen. Ph.D. Thesis. Aachen: Rheinisch-Westfälischen Technischen Hochschule Aachen.

[8] Goenka P. K., Oh K. P. (1986). A Short Bearing Theory for the Elastohydrodynamic Solution of Journal Bearings. In Transactions of the ASME. Journal of Tribology. Volume 108.

[9] Knoll G., Schönen R., Wilhelm K. (2006). Full Dynamic Analysis of Crankshaft and Engine Block with Special Respect to Elastohyfrodynamic Bearing Coupling. Universität Gesamthochschule Kassel, Germany.

[10] Gulwadi S., Shrimpling G. (2003). Journal Bearing Analysis in Engines Using Simulation Techniques. 2003 SAE World Congress, Detroit, Michigan, USA.

[11] Greenwood J. A., Tripp J. H. (1970). The Contact of two Nominally Flat Rough Surfaces, Proc. Instn. Mech. Engrs., 1970

[12] Roelands C. J. A. (1966). Correlation Aspects of the Viscosity-Temperature-Pressure Relationship of Lubricating Oils. Ph.D. Thesis, Delft: Technical University Delft, The Netherlands.

[13] Novotný P. (2009). Virtual Engine - A Tool for Powertrain Development, Inaugural Dissertation, Brno University of Technology. 